Hispania, 2016, vol. LXXVI, nº . 253, mayo-agosto, págs. 355-384

ISSN: 0018-2141, e-ISSN: 1988-8368, doi: 10.3989/hispania.2016.011

\title{
Micer García de Gibraleón († 1534), un bróker eclesiástico en la Roma del Renacimiento*
}

\section{José Antonio Ollero Pina}

Universidad de Sevilla

jaollero@us.es

RESUMEN: Los conversos se pueden entender como un grupo definido que adoptó incluso conductas comunitarias, pero en su seno se encontraban situaciones sociales y culturales muy diferentes, de manera que su historia debe reconstruirse a partir del estudio de individuos y familias múltiplemente interrelacionados y que vivieron trayectorias muy diversas. García de Gibraleón (†1534) representa un caso ejemplar de supervivencia y adaptación. Hijo de Pedro Fernández Benadeva, uno de los primeros condenados y ejecutados por la Inquisición sevillana, ya a principios de 1481, y de una madre cuyo rastro se pierde en el destierro, nunca regresaría a su ciudad natal. Sin embargo, desde Roma y durante el primer tercio del XVI, valiéndose de la posición a la que había escalado en el medio curial, estuvo en condiciones de actuar como un intermediario imprescindible, un auténtico bróker, del mercado de las sinecuras y los beneficios eclesiásticos y ponerse al servicio de varias iglesias españolas, entre ellas de la de Sevilla, de donde sus hermanos tuvieron que abandonar sus prebendas para salvar sus vidas, al mismo tiempo que se hacia con un apreciable patrimonio. Hasta en el legado que dejó al morir significó la trágica ironía de aquel tiempo de angustia.

\section{Palabras clave: Conversos; Inquisición; Sevilla; Curia pontificia; Beneficios eclesiásticos; Patronazgo.}

\section{Micer García de Gibraleón († 1534), an ecclesiastical broker in Renaissance Rome}

* Archivo Catedral de Sevilla (ACS), Archivo General de Simancas (AGS), Archivio Segreto Vaticano (ASV), Archivio Storico de Propaganda Fide (ASPF), Archivo Histórico Provincial de Sevilla Protocolos Notariales (AHPSPN), Actas Capitulares (AACC), Fondo Histórico General (FHG), Registro General del Sello (RGS). 


\begin{abstract}
The conversos can be regarded as a group which adopted even a sort of a communitary behavior, although within it one could find very different social and cultural situations. Therefore, their history must be reconstructed from the study of individuals and families which trajectories intertwined in many ways, and who lived very diverse experiences and personal developments. García de Gibraleón (†1534) represents an exemplary case of survival and adaptation. Son of Pedro Fernández Benadeva, one of the first persons convicted and executed by the sevillian Inquisition in 1481, and whose mother trace is lost in exile, he will never be back to his native city. However, during the first third of the XVI $I^{\text {th }}$ century, he used his position in the Roman Curia to develop the role of the essential intermediary, the genuine broker of the sinecure market and ecclesiastical benefits. Some spanish churches, like Seville, the city from where his brothers had to abandon their prebends to safe their lives, used (and paid for) his services, while he gathered a big estate, which really symbolised the tragic irony of that time of angst.
\end{abstract}

KEY WORDS: «Judeoconversos»; Inquisition; Seville; Roman Curia; Ecclesiastical benefits; Patronage.

La figura de García de Gibraleón no es desconocida. De hecho, la historiografía clásica sevillana ha venido mencionando su nombre porque fue el fundador de la capilla y cofradía de la Anunciación o de las Doncellas de la catedral de Sevilla. Pero, excepto que, sin moverse de Roma, donde residía como escritor apostólico, las había dotado con su propio dinero en 1517, se tenían pocas noticias de su persona. Desde hace ya unos años sabemos que fue uno de los hijos de Pedro Fernández Benadeva, el mayordomo de la mesa capitular del cabildo de Sevilla que la Inquisición llevó a la hoguera en abril de 1481 por judaizante y ateo, y de Isabel Suárez, que salvó su vida huyendo a Portugal, donde tal vez supo que su efigie había sido también presa de las llamas ${ }^{1}$. Desvelado este acontecimiento, su persona adquiría unos perfiles más inquietantes. Sin embargo, ha aparecido en la historiografía reciente en dos planos distintos sin conexión entre ellos, como si se tratara de un espectro en busca de su alma. Este trabajo pretende darle cuerpo persiguiendo los elementales datos de su biografía y centrándose en la reconstrucción de su actividad como mediador entre quienes buscaron su influencia en la corte pontificia. Aunque en el mundo eclesiástico de su tiempo, entre fines del siglo XV y la primera mitad de la centuria siguiente, no signifique un caso excepcional, a García de Gibraleón se le puede aplicar la definición de bróker en el sentido que explica Kettering ${ }^{2}$. Como tal ejerció cultivando sus relaciones en el cen-

1 Sobre la familia, OLLERO PINA, 40 (Madrid, 1988); GIL, II; 41-92, especialmente, y OLLERO PINA, 2009.

2 KETTERING, 1986: 4-5 
tro dispensador de gracias en favor de varios clientes, entre los que estuvieron el cabildo catedral de Sevilla y sus prebendados, pero también otros, como Fernando el Católico. Todos ellos rindieron tributo a la posición que, sin necesidad de escalar a los peldaños superiores de la Iglesia, había alcanzado y a las habilidades que desplegaba en cumplimiento de sus compromisos, las mismas que le sirvieron para enriquecerse.

García de Gibraleón no estaba en Sevilla cuando el Santo Oficio encausó a sus padres y es atractivo imaginar que Alfonso Fernández Benadeva, su hermano, canónigo en su catedral, lo hubiese llevado a Italia consigo antes de 1480. En 1488 Álvaro, otro de sus hermanos, consiguió que los reyes cursaran cartas de protección de las prebendas sevillanas que ambos, Alfonso y García, poseían contra las acechanzas de Francisco y Rodrigo de Santillán ${ }^{3}$. Sus dispositivos quizás no se compadeciesen con la realidad, pero es la primera vez que los vemos intentando recuperar las prebendas que sentían como inherentes al patrimonio familiar, una convicción que las hogueras y las condenas de la Inquisición no habían conseguido consumir. En fecha indeterminada partió Luis de Gibraleón, el menor, en búsqueda de sus hermanos emigrados. La presencia de todos en Roma no llamaría la atención. Los españoles eran los extranjeros más numerosos en la ciudad de san Pedro y no constituía ningún secreto el origen de muchos de ellos. La vida en la capital de la Iglesia permitía el contacto continuo con Sevilla casi como si no se hubieran ido y como si preparasen el regreso a una ciudad a la que nunca volverían. Ya en 1503 García de Gibraleón optó por una mediarración de su catedral que no obtuvo $^{4}$. Para entonces sus prebendados eran conocedores de las gestiones que habría realizado a su servicio al lado de quien servía como su procurador en Roma, el obispo de Terracina, Juan Gálvez. Este eclesiástico, también natural de Sevilla y de familia conversa, pero sin un pasado tan dramático ${ }^{5}$, pudo muy bien haberlo amparado y erigirse en su modelo ${ }^{6}$. En 1479, cuando los

3 Valladolid, 20 y 24 de diciembre de 1488, AGS, RGS, 1488-12, 160, e ib. 1488-12, 191; OLLERO PINA, 2009: 565-572.

428 de abril de 1503, ACS, AACC, lib. 07054, ff. 23v-24; HAZAÑAS, 1909: 352.

5 GIL, 2000, vol. II: 64-65.

6 Obispo de Terracina en 1500. La carrera, solicitador (1482), acólito (desde 1483), scriptor (1486), abreviador (1489-1503), collector taxe plumbi (1492-1497), notario (1495), maestro del registro (1500-1506), clérigo de cámara (1503-1507), FRENZ, 1986: 373-374 (n ${ }^{\circ}$ 1.254) y RORC. Referencias biográficas en FERNÁNDEZ ALONSO, 6 (Roma, 1958): 26, 68; FERNÁNDEZ ALONSO, 4 (Roma, 1956): 515, doc. 56. La inscripción funeraria en Santiago de los Españoles, que permite establecer su nacimiento en Sevilla el 21 de septiembre de 1438, FORCELLA, vol. III, 1876: 223, n 542. Agradezco al profesor José Solís de los Santos el desarrollo de la misma. Fernández Alonso, basándose en el Liber Notarum de Burckardi, se refiere a la relación de Gálvez con el asunto de la falsificación de breves en 1497. En el contexto político, FERNÁNDEZ DE CÓRDOVA, 2005: 563-564. 
capitulares sevillanos lo eligieron como su procurador ante la corte romana, contaba con unos 41 años de edad 7 . El ejercicio de su oficio no se inició sin problemas. El cabildo le otorgó su poder sin revocar la representación que ostentaba el obispo de Osma, Francisco de Santillán, que seguía gozando de la chantría y una canonjía de Sevilla, y hubiera sido sustituido antes de acabar el año si Juan Rodríguez de Góngora, el desgraciado canónigo y arcediano de Jerez que no mucho después sería víctima de la Inquisición, no hubiera desechado un nuevo nombramiento en su lugar ${ }^{8}$. Pero en adelante Gálvez, doctor in utroque iure, hizo valer su experiencia curialesca durante un cuarto de siglo.

Cuando los prebendados lo nombraron procurador tras el desestimiento definitivo del oficio del obispo de Terracina en mayo de $1505^{9}$, García de Gibraleón era un clérigo curial experimentado que disfrutaba de una cierta opinión. La fama de su habilidad negociadora debió de primar sobre las reticencias que pudo causar su ascendencia familiar. Si el acomodo en la burocracia romana exigía dinero y patrocinio ${ }^{10}$, en 1495 el hijo de Pedro Fernández Benadeva disponía de suficiente del primero para dotar la capilla de la Natividad de Jesús en Santiago de los Españoles ${ }^{11}$. Un año después ya figuraba como scriptor cancellarie, el primero de sus oficios en la curia y que, conservándolo durante toda su vida, junto con el de solicitador, le procuraba mayor capacidad de influencia ${ }^{12}$. Como escritor apostólico se inscribió en la lápida del protonotario Pedro Fernández, fallecido en 1502, que hizo colocar en la misma iglesia en que dotó su capilla ${ }^{13}$. Julio II lo llamaría clérigo sevillano, escritor y abreviador apostólico, nuestro familiar y notario, en una bula de 1507 en la que concedía por su intercesión una indulgencia a los fieles que

713 de septiembre de 1479, ACS, AACC, lib. 07050, f. 17v.

817 de septiembre-18 de noviembre de 1479, ACS, AACC, lib. 07050, ff. 18, 21v-23. El primer asunto que se le encomendó, el 21 de diciembre. fue la defensa de los intereses del cabildo contra el obispo de Osma, ACS, AACC, lib. 07050, f. 27v.

97 de mayo de 1505, ib., f. 114rv. Según su lápida citada, Gálvez fallecería el 6 de agosto de 1507.

${ }^{10}$ En el sentido que establece PARTNER, 1990.

${ }^{11}$ VÁZQUEZ SANTOS, 2007, vol. II: 671.

12 Scriptor cancellarie (1496-1532), solicitador (1499-1532), abbreviator (de parco minore) (1501-1521), notario (1501), scriptor archivii Romane curie (1507), comes palatinus (1514), FRENZ, 1986: 337 ( $\mathrm{n}^{\circ}$ 825) y RORC. Un informe de una comisión cardenalicia sobre los abusos de la curia durante el pontificado de Alejandro VI señalaba a un «Garsias» como el más destacado ("optimus artifex») de los oficiales autores de corruptelas en los registros de súplicas, HOFMANN, 1914, vol. II: 234. No se le debe condenar sin pruebas pero parece el sospechoso más probable.

${ }^{13}$ Hazañas recoge la inscripción de Justino Matute, quien reprodujo una versión, HAZAÑAS, 1909: 246; MATUTE, 1886, vol. I: 316. La transcripción, seguramente más correcta pero con el error de «Gibralpon» por «Gibraleón», en FORCELLA, vol. III, 1876: $\mathrm{n}^{\circ}$ $536,221$. 
asistiesen el primer sábado de cada mes al canto de la Salve Regina en la capilla de la Antigua de la catedral de Sevilla ${ }^{14}$. Sabiendo que no poseía ninguna posición jerárquica en la institución a la que servía, no obstante, García de Gibraleón sería bien consciente del poder difuso que comportaba su oficio con las posibilidades que le brindaba la información privilegiada que disponía para manipular el mercado de los beneficios de su iglesia y su diócesis. El importe del salario que se le asignó no explica la conservación de la fidelidad que demostró ${ }^{15}$. Desde el día en que fue nombrado estuvo al servicio del cabildo del que habían tenido que salir sus hermanos acosados por el Santo Oficio y asumió los negocios propios de su representación. Todo esto costaba dinero y, aparte de su salario, el procurador tenía que recibirlo puesto en Roma. No es necesario explicar que, cuando se hizo cargo de la procuración, el circuito de trasvase de numerario ya existía. Una vez que había sido librado por el cabildo, el dinero llegaba a manos de Gibraleón por medio de los banqueros genoveses o bien se entregaba a quien tenía sus poderes en Sevilla. Un tal Agustín de Cuenca, beneficiado de la iglesia sevillana de Santiago, había cuidado de los asuntos de Terracina al final de su mandato ${ }^{16}$. Francisco Suárez fue el procurador de su hermano hasta su muerte, acaecida hacia 1520 , siendo sustituido por Fernán Ruíz de Hojeda ${ }^{17}$. A ellos llegaban los envoltorios con las cartas y escrituras que enviaba Gibraleón desde Roma para el cabildo y para particulares que le encomendaron sus asuntos. Estas operaciones implicaban el sobreprecio del crédito y del giro cambiario, mucho mayor el primero que el segundo ${ }^{18}$.

García de Gibraleón recurrió a estos expedientes y, aunque, en apariencia, la corporación estaba dispuesta a gastar de su hacienda la cantidad necesaria para ganar los litigios, resultaba siempre ventajoso que un procurador dispusiera de un capital que le permitiera adelantar los gastos. Además, el cabildo

${ }^{14}$ La bula, Roma, 22 de octubre de 1507, SÁNCHEZ HERRERO; ÁLVAREZ MÁRQUEZ, 46: 126 (Madrid, 1989): 174-175.

1550 ducados anuales, 9 de mayo de 1505; 70 el 13 de septiembre de 1506, 50 por procurador y 20 para un solicitador, y 100 en 4 de febrero de 1510, ACS, AACC, lib. 07053, ff. 115, 170v, 291v. Liquidaciones de su salario entre 1505-1518, GIL, 2000, vol. II: 80.

163 de julio de 1504, ACS, Contaduría, lib. 10471, f. 30v.

17 Francisco Suárez aparece por última vez el 9 de marzo de 1518, ACS, Mesa Capitular, lib. 01558, s. f. Ruíz de Hojeda ya figura con la misma función cobrando su salario y gastos de 1520 el 3 de octubre de 1521, ACS. Mesa Capitular, lib. 07641, f. 90. En adelante solo él, 17 de noviembre de 1524,7 de febrero y 17 de junio de 1530 , ff. $91 \mathrm{v}, 99,101 \mathrm{v}$.

18 A 385 mrs. se pagaron en Sevilla los 15 ducados que el cabildo debía a Antonio de Medrano el 6 de mayo de 1502, pero fueron 50 reales por los 100 ducados que llevó Diego Godo el 20 de septiembre de 1503, un 4,5 \%, ACS, Contaduría, lib. 10471, ff. 10v, 22v. Los 110 ducados que recibió Godo del banco de Stefano Senuche, en Roma, costaron 187 florines, un sobreprecio del $19 \%$, en Sevilla el 22 de octubre del año siguiente. Por los 100 ducados que tomó Gibraleón 41.568 mrs. el 8 de octubre de 1546, el $11 \%$, ib., ff. 33v, 81. 
sabía que tales desembolsos no se podían calcular solo sobre el precio tasado de los procedimientos de la curia. Raramente, como ocurrió con el largo pleito que sostuvo por el mantenimiento de Antequera dentro del arzobispado de Sevilla, sus intereses coincidían con los del arzobispo. En 1510 consintió que Gibraleón «gaste para la delyberacyón de esta causa todo lo que le paresyere, ansy para adquirir fauor como para reducyr qualquier vexacyón o agrauyo que le fizieren en fauor de nuestra justicya» ${ }^{19}$. La voluntad real, no la falta de dinero, hizo que el pleito se perdiese. Tres décadas después, en 1546, instruyó a Francisco Mudarra, un personaje aún más intrigante, su procurador entonces ${ }^{20}$ :

tenga mucho cuydado de todo lo que convenga a la presta y buena expediçión de los dichos negoçios, para lo qual le encargaron y mandaron que, si le paresçiere que conviene, de los dineros que en su poder tuviere del cabildo pueda dar y dé a la persona o personas que viere que conviene, ansí auditores de Rota e a sus agentes e notarios, como a otros personas, la propina o propinas que bien visto le fuere, y asímismo a los notarios ante quien la dicha cabsa pasare les pueda dar e dé la bibalia o bibalias que viere que conviene a la presta y buena expediçión de la justicia del cabildo ${ }^{21}$.

Las inversiones en procesos judiciales nunca fueron un capítulo sobresaliente de los gastos de la mesa capitular, pero estos consejos a un hombre que no los necesitaba nacían de la experiencia contrastada en las causas que se seguían en los tribunales romanos y, paradójicamente, permiten moderar las dimensiones de sus corruptelas burocráticas con la confirmación de que su maquinaria debía de ser engrasada. Alonso de Molina estaba en Roma cuando su procurador, el mismo Francisco Suárez, presentó unos ejecutoriales en Sevilla en 1507 que le valieron la posesión de un canonicato de su iglesia ${ }^{22}$. Seis años después el cabildo lo enviaba a la corte pontificia para que gestionara la confección de una serie de bulas y besara los pies del nuevo pontífice, León $\mathrm{X}^{23}$. Regresó a los pocos meses habiendo cumplido con lo que se le confió y con una indulgencia para la fábrica de la catedral ${ }^{24}$. Recordando el éxito de ese viaje, su compañeros le cometieron en 1515 que procurara otra semejante e insistiera en el engorroso pleito antequerano, agraciándole con una generosa remuneración ${ }^{25}$. Molina, por consiguiente, que conocía bien a García

${ }^{19}$ ACS, AACC, lib. 07053, f. 291v.

${ }^{20}$ OLLERO PINA, (Salamanca, 2005): 171-176.

${ }^{21} 1$ de enero de 1546, ACS, AACC, lib. 07066, f. 41.

229 y 10 de julio de 1507, ACS, AACC, lib. 07053, ff. 235v, 236.

${ }^{23} 22$ y 22 de abril de 1513, ACS, AACC, lib. 07056, f. 34rv.

${ }^{24} 23$ de enero, 13 de marzo, 3 de abril, 30 de mayo de 1514, ib., ff. 77v, 86, 88v, 98v-99.

2512 de septiembre de 1515, ACS, AACC, lib. 07057, f. 53. En junio de 1516 se le pagaron 60.000 mrs., ACS, Mesa Capitular, lib. 01558, s. f. Se aumentó el salario a 200 ducados y a 250 anuales que pasaron a 100.000 mrs. en 1518, 6 de abril y 13 de mayo de 
de Gibraleón y su familia, no era un novato en las lides de la curia, sino un hábil negociador que poseía un fácil acceso a sus círculos de poder gracias a la experiencia romana que también utilizaba para su beneficio ${ }^{26}$. Durante el primer año en Roma presentó una factura de unos 200 ducados y en febrero de 1518 el cabildo le giró otros 100 para el despacho de dos bulas ${ }^{27}$, pero temía que los prebendados quisieran vencer sin desembolsar, cosa imposible que, en la carta que les escribió en agosto de 1518, prometió solventar «con el ingenio» del que presumía avisándoles de cómo se conseguían las cosas en tan santa ciudad:

Señores, pues estoi en parte que, aunque jure a Dios, no hecharán tres mill mrs. de pena, digo que, ¡Cuerpo de Dios!, que no se toman truchas a bragas enxutas. Que vuestras merçedes abran las orejas i las bolsas i no quieran lo que es contra natura, casi hazer sus negoçios i que les den dineros ençima. I digo que es menester, ultra todo lo dicho, para endulçar la boca de todos estos señores con quien se a de negoçiar i hazelles venir gana de fauoresçer la justiçia, que me enbíen para presentar algunas cosas i no pocas, como son guadameçiles, guantes, cueros de borzeguíes, oliuas, cosas labradas. I esto todo mui bueno i mui perfeto porque tal para qual. I aún algo para el Papa, como sería o una gentil mula o un gentil cauallo. I, si esto bien les paresçiere i lo deliberaren hazer, a de ser luego i que venga un ombre propio con ello mandado de vuestras merçedes. I aún para el Papa me paresçería bien que enbiasen algund olio de aquello mui singular de Éçija i un par de botas de vino, una blanca i otra de halo, que fuesen mui singulares. I desta manera se negoçia i algunas frasquerías de las Indias, que todo plaze i allá avrá algunos señores que podrán dezir lo que será bueno ${ }^{28}$.

Cuando reprendía de esta manera, Molina quizás ignorara que su cabildo ya había ordenado que se destinasen 30 ducados del importe de la indulgencia a «cosas de acá compradas, como guantes e otras semejantes, para gratificar allá a personas en Roma para que se hagan bien los negoçios tocantes a esta

1517, 14 de julio de 1518, ACS, AACC, lib. 07058, ff. 18v-19, 34, 156v.

${ }^{26}$ En la dotación de su capellanía Molina ordenó una memoria por el cardenal Ascanio, que no puede ser otro que Ascanio Sforza (1455-1505), del que fue probablemente familiar, 3 de enero de 1537, ACS, AACC, lib. 07061, f. 78; 31 de mayo de 1538, ACS, FHG, Caj. 41, 1, y ACS, II. Mesa Capitular, lib. 09138, no 433, ff. 179v-180v. León X en 1513 lo trataba de familiar y notario, HERGENRÖTHER, 1884: ${ }^{\circ}$ 404, 4435. En una bula de indulgencias para los que visitasen la catedral de Sevilla de 1 de septiembre de 1516 lo trata como como "dilectus filius, magister Alfonsus de Molina, notarius et camerarius noster». En otra similar como "dilectus filius, magister Alfonsus de Molina, canonicus Ispalensis, notarius et familiaris noster, continuus comensalis ac litterarum apostolicarum solicitator», SÁNCHEZ HERRERO; ÁLVAREZ MÁRQUEZ, 46: 126 (Madrid, 1989): 134, 175, 177.

${ }^{27}$ Según el mandamiento de pago de 7 de noviembre de 1516, ACS, IV, lib. 09369, f. 7. Sobre ambas bulas, 5 de febrero de 1518, ACS, AACC, lib. 07058, f. 108.

${ }^{28}$ Roma, 15 de agosto de 1518, ACS, FHG, Caj. 54, 31. 
dicha Santa Iglesia» ${ }^{29}$. De saberlo, consideraría esta cantidad insuficiente. La negociación exigía emplear las armas de seducción de las voluntades, como de esta manera tan gráfica y plena de humor mostraba en su correspondencia. Incluso la del Papa Médici podía ablandarse, no ya con una mula o un buen caballo, sino con aceite selecto de Écija y vino de calidad, y a él y a su cardenal nepote había que encomendarles el negocio cuando tuviesen decidido qué presentes les iban a enviar. También tendría que recomendarse a los cardenales de la signatura. Había ideado una estrategia persuasiva adaptada al dinero del que podía disponer, siempre escaso para alimentar tantas bocas hambrientas, que necesitaba la colaboración de García de Gibraleón, a quien el cabildo y fr. Diego de Deza, el arzobispo, debían remitirle cartas «diziéndole que se recuerde que muchas vezes a escrito a vuestras merçedes que esta causa la quiere tomar por honra». Las gestiones de los dos aliados fracasaron, pero la honra profesional del conseguidor que era Gibraleón no hubo de verse afectada ni siquiera cuando el cabildo comisionaba a otros prebendados para que lo representase circunstancialmente en Roma. Ésta situación podía darse con frecuencia porque no fueron pocos los que residieron en ella en la primera mitad del siglo XVI o que viajaron para solucionar sus asuntos. En 1529 se envió al mediorracionero Alonso Álvarez de Baeza como solicitador de pleitos. Se le prometió su prebenda como salario durante tres años y se le advirtió que García de Gibraleón permanecería como procurador principal ${ }^{30}$. Cuando se cumplió este plazo, se le escribió a éste que le notificara que debía de volver a Sevilla porque «donde está vuestra persona no tenemos neçessidad en essa corte de otro ningund procurador» ${ }^{31}$.

Esta declaración no significa que se esperara a 1532 para reconocer los servicios que García de Gibraleón había rendido porque no hubo causa o asunto cuya resolución dependiera de Roma en que no hubiese intervenido desde $1505^{32}$. Por su parte, él mismo procuró que su memoria y la de su familia no se perdiese en su iglesia cuidando los vínculos, tanto afectivos como materiales, que lo unían a ella y a la ciudad. Un dulce recuerdo de la infancia anterior a la tragedia le inspiró la petición que valió la mencionada indulgencia del canto sabatino de la antífona Salve Regina de la Antigua. Figuraba en el tenor de la bula como un antiguo parroquiano de la collación de Santa María, la catedral, que compartía con sus vecinos la devoción a la pintura de la Vir-

2928 de junio de 1518, ACS, AACC, lib. 07058, f. 148v.

${ }^{30}$ El cabildo a García de Gibraleón, 13 de abril de 1532, ACS, FHG, 179, 36. Las instrucciones a Álvarez de Baeza, 4 de junio de 1529, ACS, AACC, lib. 07077, 44rv.

${ }^{31}$ El cabildo a García de Gibraleón, 13 de abril de 1532. Álvarez de Baeza respondió que no podía regresar tan presto, 4 de septiembre de 1532, ACS, FHG, 179, 36. Nunca volvería a Sevilla.

${ }^{32}$ Para una relación, GIL, 2000, vol. II: 37-38, 81. 
gen que había en aquella capilla ante la que se congregaba una multitud de fieles. Tal parecía como si fuera a regresar a su ciudad natal para participar en un culto que había ido en aumento desde hacía medio siglo mientras crecía en su entorno una liturgia con toda solemnidad coral $^{33}$. Pero es que todavía daría otros pasos para reforzar la relación con su cliente, la iglesia de Sevilla, y salvar su ausencia con la huella de su persona y de su linaje.

Se antoja irónico que fuese García de Gibraleón quien procurase la confirmación pontificia del estatuto de limpieza que fr. Diego de Deza y el cabildo decidieron imponer el 12 de febrero de 1515. El «Quantum in vinea» incluía para su abominación pública los nombres de sus hermanos Alfonso y Juan y establecía «que de aquí adelante no se admita por benefiçiado desta sancta iglesia nieto ni fijo de condemnado por el crimen e delicto de heregía ${ }^{34}$. Sin embargo, nadie observó contradicción en que, mientras se gestionaba la confirmación de León $X$, en septiembre del mismo año se le premiase «en respeto a los muchos seruiçios que ha fecho en esta dicha Santa Yglesia e faze el dicho Garçía de Gibraleón e quánto esta dicha Santa Yglesia ha ganado por él» con el enterramiento que había pedido en la catedral para él, sus hermanos y sus sobrinos en un altar cabe la capilla de Nuestra Señora de la Antigua $^{35}$. La gracia unánime la ampliaría el cabildo dos años después atendiendo la solicitud de su procurador de una capilla a la que se trasladaría la sepultura familiar, que incluiría la de Francisco Suárez y su mujer, la misma que solo dos años atrás había sido castigada por el Santo Oficio, y donde residiera una cofradía que quería hacer "para casar donzellas nesçesitadas» ${ }^{36}$. Gibraleón sabía que su petición sería satisfecha. Cuatro meses después, en las bulas que daban sustento canónico a la capilla y a la hermandad, se afirmaba que este clérigo hispalense, notario y familiar pontificio, se había movido por su singular devoción a la gloriosísima Virgen María y a su Santa Anunciación. Este legado sería el que finalmente garantizaría la pervivencia en la ca-

${ }^{33}$ El tratamiento de esta cuestión reviste una importancia mayor que la que aparenta y en la que no podemos extendernos.

${ }^{34} \mathrm{La}$ adopción del estatuto ese día. La aprobación por el arzobispo y el cabildo, el 21 de marzo, ACS, AACC, lib. 07056, ff. 110v-111, 114. El texto en ACS, Secretaría, lib. 07423, ff. 43v-44. Con ligeras variantes en la edición impresa de la segunda mitad del XVI, Estatutos y constituciones de la Santa Iglesia de Sevilla, ff. 170-171.

3514 de septiembre de 1515, ACS, AACC, lib. 07057, f. 54v. Para la emisión de la bula confirmatoria del estatuto es posible que actuara Alonso de Molina con Gibraleón. La bula, León X, Roma, XII kal. de septiembre (21 de agosto) de 1516, ACS, FHG, Caj. 62, 2. El 20 de marzo de 1515 el cabildo ordenó girar 100 ducados a Gibraleón «para el despachar las bullas de los estatutos desta Sancta Yglesia» y la de la indulgencia plenaria de la iglesia, ACS, AACC, lib. 07057, f. 3v. El 26 de noviembre se pensó en enviar un beneficiado a Roma para defender el estatuto sine revocatione aliorum procuratorum, ib., f. $69 \mathrm{v}$.

3627 de febrero de 1517, ACS, AACC, lib. 07058, ff. 12v-13 y GIL, 2000, vol. II: 442. 
tedral y en la memoria urbana de su nombre y de su propia imagen, tal como hoy se conserva pintada por Cristóbal de Morales. Es posible que la tesis de Gil sobre la oposición anticonversa del sector intransigente del cabildo a su fundación sea correcta. Su explicación supone, además, que García de Gibraleón concibió la constitución de una cofradía que agrupara a los miembros de la familia y otros conversos sevillanos que se sintieran identificados con su origen en que se reprodujeran los mecanismos de solidaridad del pasado. $\mathrm{Su}$ análisis funcional y sociológico, que este mismo autor inicia, parece abonar esta interpretación. Pero, como igualmente pone de relieve, Gibraleón era miembro de la cofradía romana de la Caridad y no habría que salir de Sevilla para asistir a la creación de instituciones benefactoras similares. En realidad, el modelo caritativo se hallaba en la misma Roma. La "Confraternita dell'Annunziata», que radicaba en Santa Maria sopra Minerva, se dedicaba desde 1460 a dotar doncellas y no es aventurado imaginárselo asistiendo a la visita que le hizo León X, su patrón, en $1513^{37}$.

No se puede dudar de que a García de Gibraleón le interesaba mantener el vínculo con la iglesia de Sevilla, pero su prestigio como mediador superaba su ámbito. Desde Roma trabajaba para otros. Alonso de Morales en su testamento, en 1506, declaraba el «muncho amor que entre él e mí a avido syenpre, asy en tiempo que nos comunicamos en persona como después acá ${ }^{38}$. Tan íntima amistad obliga a preguntarse dónde coincidieron. En 1493 Morales residía en Sevilla sirviendo la canonjía a la que había accedido poco antes gracias a Diego Hurtado de Mendoza y estuvo en ella hasta principios de $1495^{39}$. En adelante, el tesorero de la reina solo se movería con la corte sin olvidarse de favorecer al cabildo ${ }^{40}$. Gibraleón, por consiguiente, solo tuvo oportunidad de tratarlo antes de 1493 o después, si frecuentó los círculos cor-

37 GRASSI, 1884: 1-2. Sobre esta cofradía y su capilla el comentario del editor, ib., 97. También, HERGENRÖTHER, 1884: nº 2189/2190. Sobre su actividad posterior, D'AMELIA, 1990. Sucinta exposición de las cofradías romanas coetáneas, PARTNER, 1979: 104-105. El ceremonial de entrega de dotaciones en la cofradía sevillana recuerda al que se seguía en la cofradía romana según lo describió Montaigne, DELUMEAU, 1957-1959, vol. I: 430. No es casual que la iglesia de Santiago de los Españoles, primero, y la cofradía de la Santísima Resurrección, creada en 1579, también dotara doncellas y reprodujera rituales y calendarios idénticos, DANDELET, 60: 3 (Chicago, 1997): 505-509; DANDELET, 2003: 206-211.

${ }^{38}$ Cláusula del testamento, Valladolid, 24 de abril de 1506, AGS, Diversos, leg. 37, 18. Lo citan para la relación entre Morales y Gibraleón, CARRETERO ZAMORA; ALONSO GARCÍA, 2003: 22. También, ANDRÉS, 2004: 21.

${ }^{39}$ Como canónigo por vez primera en ACS, Mesa Capitular, lib. 08079. El 1 de abril de 1493 rubricaba un estatuto capitular como canónigo y "notarius», ib., lib. 09138, f. 156. Su salida de Sevilla, ACS, FHG, Caj. 104, 5/4c.

${ }^{40} \mathrm{El} 25$ de enero de 1503 el cabildo le otorgaba horas «porque tiene cargo en la corte del rey e de la reyna, nuestros señores, de procurar los negosios de este cabildo y desta Santa Iglesia con sus altesas e con las otras personas que conviene», ACS, AACC, lib. 07054, f. 6. 
tesanos antes de marcharse a Italia. En cualquier caso, la correspondencia permitió que procurase los asuntos beneficiales de su antiguo amigo. Morales se refería a que él resolvería la promesa hecha al licenciado Álvaro Yebra de obtenerle una pensión sobre el arciprestazgo de Maqueda en recompensa de la renuncia del arcedianato de Canarias en favor de Francisco de Bobadilla. Quién fuese este último adquiriría sentido en el futuro. Mientras que Yebra era, cuando testaba, inquisidor del tribunal sevillano y algo debería a Gibraleón, quizás la mediarración que poseía desde dos años antes ${ }^{41}$, Bobadilla, que operaba en Sevilla como mayordomo y factor del tesorero, había tomado posesión en 1505 de la chantría de su cabildo en su nombre ${ }^{42}$. En 1509, siendo prior de San Salvador de Sevilla, sería nombrado sucesivamente obispo de Ciudad Rodrigo y Salamanca ${ }^{43}$.

La confianza de Alonso de Morales demuestra que las habilidades de García de Gibraleón ya eran conocidas en la corte. En 1510 Fernando el Católico aleccionó a su embajador en Roma, Jerónimo de Vich, para que averiguase la situación en que se hallaba el pleito entre Diego Colón e Isabel de Gamboa informándose del procurador de ésta, es decir, de García de Gibraleón ${ }^{44}$. Es la primera vez que el rey buscara su mediación, pero ya no sería hombre que pasara desapercibido. En febrero de 1515 Vich recurrió a él y a otro curial compatriota, el obispo de Alger, Juan de Loaysa, para que Pedro de Barahona, un escritor apostólico español condenado por asesinato, fuese absuelto a cambio de que la Inquisición levantara la sentencia contra el maestre Hernando, el médico de León $X^{45}$. Su dudoso éxito no impidió que Gibraleón continuase como agente de varios clientes, entre ellos el monarca y su embajador. Precisamente, que lo fuera de Sancho de Matienzo explica que Fernando acudiera de nuevo a su habilidad. Solo unos días antes el rey había escrito a Vich recomendándole que, para que el Papa concediera al tesorero de la Casa de la Contratación la abadía de Jamaica, siguiera las directrices que Gibraleón le indicase mientras que enviaba al mismo tiempo una carta a éste agradeciéndo-

${ }^{41}$ Diego López de Cortegana presentó las bulas y tomó posessión, ACS, AACC, lib. 07054, f. 26v; HAZAÑAS, 1909: 358. Horas como inquisidor el 4 de octubre, ACS, AACC, lib. 07054 , f. 51.

42 24-25 de junio de 1505, ib., lib. 07053, f. 124rv; HAZAÑAS, 1909: 299-300. Como arcediano de Canarias, receptor de diversas rentas, CARRETERO ZAMORA; ALONSO GARCÍA, 2003: 7, 147, 148, 152, 154.

${ }^{43}$ FRENZ, 1986: 126 (No 683); RORC. En EUBEL, 1960, vol. III: 168, 289.

${ }^{44}$ CARRETERO ZAMORA; ALONSO GARCÍA, 2003: 22; CARRETERO ZAMORA, 78 (Buenos Aires, 2003): 7; ALONSO GARCÍA, 2004: 193.

45 Jerónimo de Vich al ¿Secretrario Quintana?, Roma, 6 de febrero de 1515, TERRATEIG, 1962, vol. 2: 326-327. Sobre Loaysa, EUBEL, 1960, vol. III: 104: FRENZ: RORC. El caso de Pedro de Barahona, 9 de febrero 1515, HERGENRÖTHER, 1884: $\mathrm{n}^{\circ}$ 14054. 
le sus servicios y encomiando las cualidades que Matienzo le había elogia$\mathrm{do}^{46}$.

De la ramificación de los contactos de García de Gibraleón vislumbramos una parte. A la espera de una pensión, fr. Francisco Ruíz, el secretario de Cisneros y obispo de Ávila, le escribía en 1517 a Diego López de Ayala que «bien sería que su al[teza] escriviese a Gibraleón, encargándole y diziéndole que sería seruido en que esto a la hora lo concluyese ${ }^{47}$. Olvidando la exageración, la frase revela que se pensaba que el joven Carlos tenía hilo directo con el curial y que éste podía solucionar lo que se propusiera. Alonso de Molina informaba al cabildo en su carta citada que el cardenal de San Jorge, Rafael Riario, negociaba con el escritor apostólico Juan de Lerma cederle su obispado de Málaga. Si la provisión se llevaba a cabo, el objetivo del cabildo se cumpliría porque Lerma - afirmaba - «es ánima i cuerpo de miçer Garçía de Gibraleón, por manos del qual io creo que se haze esta contrataçión. Dígolo porque en tal caso, seiendo el dicho miçer Garçía instruto en esta causa de Antequera talmente que pro i contra, creo que por lo que della sabe la podría dar vençida a quien quisiese». Sus esperanzas se frustraron y Cesare Riario sucedió en la mitra malagueña ${ }^{48}$, pero con estas palabras testimonió su confianza en Gibraleón, cuya relación con Juan de Lerma era, en efecto, estrechísima. Éste canónigo de Burgos, que jamás sería obispo, miembro de una familia presente en la mercancía, el regimiento y la iglesia de esta ciudad, se encontraba en la curia desde 1502, a donde habría sido llevado por sus tíos, Alfonso y Gonzalo, también prebendados absentistas del mismo cabildo ${ }^{49}$.

46 Valladolid, 29 de enero de 1515, GIL, 2000, Vol. II, 38. La correspondencia del asunto comprende esta carta, AGI, Indiferente General, 419, lib. 5, f. 380v, y, de la misma fecha, dos del rey a Vich y una a León X, ib., ff. 379v-380v. Sobre los problemas con que se encontró Gibraleón para la emisión de la bula la carta de Fernando a Vich, Aranda del Duero, 2 de agosto de 1515, ib., f. 448r. Su intervención ya en WRIGHT, 36 (Oxford, 1921): 74-75.

${ }^{47}$ Roa, 20 de octubre de 1517, FUENTE, 1875: 171.

${ }^{48}$ El cardenal Riario administraba la sede de Málaga desde el 12 de abril de 1518, EUBEL, 1960, vol. III: 233.

49 Alfonso, prior de la iglesia de Burgos, fallecido c. 1523, era scriptor cancellarie en 1492 y, como Gálvez, se vio implicado en el fraude de Bartolomé de Flores en 1497. No obstante, protonotario desde 1506 y scriptor brevium en 1513, FRENZ, 1986: 275-276 (nº 94); RORC. Sería el protonotario Lerma que, escribiendo desde Bolonia el 10 de noviembre de 1510, intervino en el proceso abierto por asesinato contra el arcediano de Briviesca, asimismo Juan de Lerma, que quizás fuera su hermano, ORTEGA MARTÍN, 1973: 184-187, 342. Gonzalo era canónigo de Burgos y doctor en decretos. Procurator in audientia litterarum contradictarum (1493), solicitador (1496), scriptor cancellarie (1501) y notario (1509), con Gibraleón, conde palatino en 1514, FRENZ, 1984: 343 ( $\mathrm{n}^{\circ}$ 894); RORC. Juan ascendería en su carrera más que éste y sus tíos: scriptor cancellarie (1502-1521), abbreviator de parco minore (1508-1521), notario y scriptor penitentiarie (1513) y comes palatinus como los demás, sería caballero de San Pedro (1520) y secretario (1519) y clérigo de cámara (1521), FRENZ, 1984: 377 (nº 1284); RORC. Estos oficios se apreciaban entonces en 5.500/6.200 y 15.000 ducados, respectivamente, 
Signo de su amistad, heredaría sus beneficios y pensiones burgaleses a su amigo sevillano, quien según percibía sus rentas, administradas por otro pariente y canónigo de Burgos, Alonso de Lerma, fue abonando la pequeña asignación legada a las hermanas monjas de Juan y pagaría como tutor la dote matrimonial de Leonor, la hija que éste había dejado al morir en $1523^{50}$.

Pero García de Gibraleón no necesitó que sus amigos le donasen rentas eclesiásticas. En 1543 el clérigo sevillano Lázaro García Ordóñez escribía dolido al cabildo, cuando ya sabía que dejaría de ser su procurador en Roma para ser sustituido por Francisco Mudarra, que:

a lo que dizen de García de Gibraleón y de los otros, digo que se hizieron y hazen muy bien pagar y se pagan de su mano o les pagan las partes, que no ay nadie tan mal comedido que no siente y conosce al menos que es cargo de conciencia lleuar el trabajo ageno. Y saben todos que [...]gar de la materia que pasaua por sus manos le quedaua regresso o accesso o pensión o qualquier bocón, como dezía el maestrescuela Pinello, que jugaua pegar al estoque, cosa señalada y pieça tocada ${ }^{51}$.

Contestaba así las alabanzas que le habrían remitido de las cualidades del desaparecido procurador del cabildo, pero lo que contaba citando a Jerónimo Pinelo, que había fallecido hacía más de veinte años, era verdad. García de Gibraleón había sido un esgrimista de los beneficios eclesiásticos, el perfecto cazador de beneficios al que aconsejará Páez de Castro ${ }^{52}$. Si en 1507 volvió a fracasar con una mediarración sevillana, seis años después, en 1513, logró en disputa con García Salinas, un renombrado cantor de la capilla pontificia, hacerse con un canonicato ${ }^{53}$. Solo lo mantuvo unos meses, pero no tuvo tanto interés en conservarlo porque poseía la capacidad de arbitrar la concesión de las prebendas del cabildo sevillano que se dirimían en Roma y de beneficios eclesiásticos de otras partes. Éste era el blanco al que apuntaba su espada, favorecer a sus clientes, mejor si pagaban, y más todavía a sus parientes y a él mismo porque, como dijeron Pinelo y Lázaro García, algo se le pegaba. Seguramente, gracias a su intercesión y su financiación su hermano Luis ingresaría

FRENZ, 1984: 223, 229. El 3 de mayo de 1513 León X le confirió un canonicato de Burgos, HERGENRÖTHER, 1884: n $^{\circ}$ 2400. Hubo otro Lerma, García, en la curia, escritor de breve (1513-1515) y abbreviator de parco minore (1515), FRENZ, 1984: 337 ( $\left.\mathrm{n}^{\circ} 826\right)$; RORC.

${ }^{50}$ El 19 de marzo de 1513 León X le otorgó un canonicato de Sevilla, pero no quedan rastros de esta concesión, HERGENRÖTHER, 1884: $n^{\circ} 336$. Sobre los ingresos de las rentas que heredó Gibraleón véase después.

${ }^{51}$ Roma, 13 de octubre de 1543, ACS, FHG, 71/26 e. El 31 de julio de 1545 el cabildo le revocó los poderes, ib., AACC, lib. 07067, f. 232rv.

52 BATAILLON, 1973: 91-94.

${ }^{53}$ GIL, 2000, vol. II: 39. Salinas en la capilla de Alejandro VI desde 1502, LLORENS, 18 (Barcelona, 1988): 624-625. Los beneficios pasaron a su muerte, siendo canónigo de Cuenca, a su colega Juan Escribano en 1522, LLORENS, 12 (Barcelona, 1957): 194, 115-116. 
en la curia como scriptor cancellarie en 1503, denominándose clérigo napolitano, tal como figuraría en la edición de la Historia Parthenopea años después $^{54}$. El menor de los Benadeva no demostraría el mismo amor por sus orígenes, pero su carrera curialesca no desmereció la suya y disfrutaba de una canonjía de Toledo cuando falleció en $1523^{55}$.

Sucediendo así en Roma, es fácil entender que García de Gibraleón lograra que su familia estuviera presente en el cabildo de Sevilla hasta mediados del siglo XVI reproduciendo la estrategia que habían diseñado su padre y su abuelo. Las peripecias de la saga de sus parientes con sus prebendas requeriría más espacio del que aquí disponemos. Pedro Suárez, un hijo de su hermano Francisco, accedió a una mediarración en 1506 y dos años después a una canonjía que mantuvo hasta varios meses después de la muerte de su tío ${ }^{56}$. La homonimia explica que se le haya confundido con Pedro Suárez de Gibraleón, desdibujándose sus identidades en una sola persona ${ }^{57}$. Pero este segundo, que estaba en Roma desde antes de 1508, cuando recibió una de las prestameras que dejó el inquisidor Álvaro de Yebra tras su fallecimiento, ${ }^{58}$ era hijo de un tío materno de García de Gibraleón y a su amparo debería el oficio de escritor de la penitenciaría que poseyó como mínimo desde $1512^{59}$. Su protector primo le cedería la sustanciosa pensión que se reservó sobre la canonjía sevillana que había ocupado tan breve tiempo y que fue peloteando entre distintos clérigos curiales hasta que, en 1520, la ocupó Rodrigo de Solís ${ }^{60}$. Pedro Suárez de Gibraleón la cobraría hasta su final, pese a que en 1529,

${ }^{54}$ Sobre este poema, obra de Alfonso Hernández Benadeva, OLLERO PINA, 2009, passim.

55 Además de scriptor cancellarie, clericus registri supplicationum (1506), scriptor brevium (1507), abbreviator de parco minore (1514), cubicularius, scutifer y notarius (1515), magister plumbi (1518) y miles Sancti Petri (1520), FRENZ, 1986: 277 (nº 112).

${ }^{56} \mathrm{Su}$ entrada en la mediarración, 3, 7 y 12 de agosto de 1506, ACS, AACC, lib. 07053, ff. 166-167v, HAZAÑAS, 1909: 344-345. Presentó bulas y tomó posesión del canonicato, 5 y 10 de abril de 1508, ib., lib. 07055, ff. 24v-25v

${ }^{57}$ El error, ya en OLLERO PINA, 40 (Madrid, 1988): 79-82, lo repite GIL, 2000, vol. II: 66-67,116-118 e ib., vol. V: 350.

${ }^{58}$ En Roma, el 7 de junio de 1508, daba poder para su posesión, ASV, Instrumenta Miscellanea, 4317, s. f.

${ }^{59}$ Como tal en la asignación de pensiones sobre beneficios en la diócesis de Zamora por León X, 24 de junio de 1513, HERGENRÖTHER, 1884: $n^{\circ}$ 3337-8, y antes, representado por el canónigo Alonso de Molina en la venta de ciertos bienes paternos junto con sus hermanos, Sevilla, 26 de enero de 1512, ACS, FHG, Caj. 49, 7/9. Aquí claramente como hijo de Juan Suárez de Gibraleón, hermano, según creo, de Isabel Suárez, la mujer de Pedro Fernández Benadeva, y Mari Fernández. Reconstruye en parte esta familia, pero sin identificar el Pedro Suárez, escritor de la Penitenciaría, con Pedro Suárez de Gibraleón, GIL, 2000, vol. IV: 149-150.

${ }^{60}$ Ahorro los avatares de la prebenda hasta que Rodrigo de Solís la obtuviera el 1 de junio de 1520, ACS, Secretaría, lib. 07433, f. 23r; lib. 07434, f. 50v. Solís, que pertenecía a una familia con notable presencia en el cabildo, había sido antes racionero, desde 25-29 de septiembre de 1510, ib., AACC, lib. 07053, ff. 320v-321. 
permaneciendo todavía en Roma, obtendría su propio canonicato ${ }^{61}$. Que tomara la posesión de la prebenda en Sevilla su sobrino Álvaro Pérez Osorio, que pronto sería mediorracionero, y que Diego Hernández de Sevilla, sobrino del citado Pedro Suárez, «el mozo», fuera también canónigo manifestaba el peso de una familia que contaba con tan poderoso valedor ${ }^{62}$. Pedro Suárez de Gibraleón aún consiguió que otro de sus sobrinos, Pedro Suárez de Robleda, heredara su canonjía, de la que se reservaba su disfrute, imponiendo su provisión en 1539 porque ni sus padres ni sus descendientes habían sido molestados por la Inquisición ${ }^{63}$. Por el contrario, cuando cuatro años antes Pedro Suárez, desde Roma, pretendió ceder la suya en su hermano, homónimo de su tío, los prebendados impidieron la ejecución de la resignación alegando la disposiciones discriminatorias del estatuto de limpieza ${ }^{64}$. Dado los antecedentes, es lícito poner en duda que se hubieran atrevido a rechazarlo si García de Gibraleón no hubiese fallecido.

El amparo de sus parientes y la mediación con sus clientes y corresponsales eran actividades que ilustraban la fortaleza de su posición y el afianzamiento de su propio enriquecimiento. Cuando en septiembre de 1520 don Alonso Enríquez de Guzmán llegó a Roma, bien vestido, servido y con dinero que pronto se esfumaría, su paisano y amigo Juan de Ocampo «dio aviso a uno de mi tierra, muy honrrada persona y muy rico y estimado en Roma, que se dize miçer Garçía de Gibraleón. El qual me llevó a su cassa y ospedó muy

${ }^{61}$ 21-26 de mayo de 1529, ib., lib. 07060, ff. 39, 40v-41v. Fallecería el 5 de junio de 1543, ACS, Secretaría, lib. 07433, f. 16v; lib. 07434, f. 37v. La serie de conocimientos de pago de los 100 ducados de la pensión desde 1522 a 1543, en ACS, FHG, 97, 20.

${ }^{62}$ El primero era hijo de Isabel Fernández, su hermanastra, y el jurado García Osorio, GIL, 2000, vol. IV: 150, aunque no lo indica. Pedro Suárez de Gibraleón lo llama sobrino en su carta al canónigo Diego de Ribera, Roma, 15 de noviembre de 1533, ACS, FHG, 97, 20/20. Probablemente, ocupó la mediarración que dejara vacante Pedro de Vargas, su primo, a fines de 1529. Moriría el 15 de mayo de 1536, ACS, AACC, lib. 07063, f. 30; ACS, Secretaría, lib. 07433, f. 41v. Su documentación testamentaria en GIL, 2000, vol. II: 97. El segundo nació del matrimonio de Leonor Suárez, hija de Francisco Suárez, el hermano de García de Gibraleón, y Alfonso Fernández de Sevilla, GIL, 2000, vol. II: 67 y vol. V: 313, 320, 350. Canónigo desde el 17 de junio de 1523, murió el 13 de octubre de 1558, ACS, Secretaria, lib. 07433, f. 14r y lib. 07434, f. 27v. Actuó en ocasiones como apoderado de Pedro Suárez de Gibraleón, que lo trataba de sobrino escribiendo al canónigo Juan de Medina, desde Amberes, el 25 de mayo de 1533, ACS, FHG, 97, 20/23. En 1536 era prior de la hermandad de las Doncellas, ACS, Hermandad de las Doncellas, I. Gobierno. Libros de acuerdos del cabildo, 1536-1554: leg.1, exp. 2 (1).

6331 de marzo-3 de abril de 1539, ACS, AACC, lib. 07064, ff. 151-153v. Suárez de Robleda gozó poco de la prebenda, envuelta en pleitos, y moriría joven, antes de los 25 años, en 1549, ACS, Secretaría, lib. 07433, f. 16v; lib. 07434, f. 37v. Era hijo de Leonor Suárez, hermana de Pedro Suárez de Gibraleón, y Diego de Robleda, GIL, 2000, vol. IV: 350, aunque el mismo autor lo sitúa como hijo de Leonor Suárez, hija de Francisco Suárez, casada con Alfonso Fernández de Sevilla, GIL, 2000, vol. V: 350.

${ }^{64}$ OLLERO PINA, 40 (Madrid, 1988) y GIL, 2000, vol. II: 113-118. 
bien, dándome de comer a su costa, a mis criados y bestias, y a mi persona, quando y como yo quería, con muy grand acatamiento ${ }^{65}$. En 1525 , con honra, riqueza y estimación, García de Gibraleón gozaba de la suficiente consideración en la comunidad española de la ciudad y en los círculos eclesiásticos partidarios del emperador como para contarse entre los avalistas del préstamo con que varios banqueros romanos habían contribuido a la financiación de la campaña imperial en Lombardía. Junto con él se hallaron otros curiales y, sobre todo, los obispos de Castellamare, el también sevillano Pedro de Flores, y el de Scalas, don Baltasar del Río, otro ínclito converso con una dramática historia familiar semejante a la suya, que a finales de ese mismo año recuperaría el canonicato que había tenido en el cabildo de Sevilla ${ }^{66}$. Un año después Clemente VII privilegiaba a Gibraleón en sendas bulas con la posesión simultánea de beneficios en la diócesis de Sevilla y en las de Toledo y Cuenca ${ }^{67}$. La gracia casi resultaría una redundancia innecesaria para un hombre que, fuese cual fuese el procedimiento que hubiese seguido para obtenerlos, había dado sentido a su vida con su acaparamiento. En 1513, por ejemplo, había logrado, entre otros, dos beneficios para sus familiares y tres más en la diócesis de Sevilla que resignó con condiciones en sus sobrinos Pedro y Gonzalo Suá$\mathrm{rez}^{68}$. Además, la posesión de tantos beneficios le permitía el juego del intercambio. Permutó así en 1521 la tesorería de Santa María de Valladolid con el beneficio de Manzanares que tenía un Fabiano Justiniano, que quedó obligado a compensarle con una pensión ${ }^{69}$. No sería la única vez. Era a esto y a la acumulación de pensiones sobre los beneficios de terceros, los aranceles que le fueron pagando los clérigos y capitulares que le debieron los suyos propios con sus tejemanejes en la curia, a lo que se referiría Lázaro García. Afortunadamente, estamos bien informados de los resultados de tanta voracidad gracias a que se han conservado la contabilidad que llevaba en Roma Gonzalo Suárez, otro de sus sobrinos, que le debía su oficio de cubiculario pontificio, y la documentación de su espolio. Ambas fuentes se complementan. Mientras que esta última plasma el momento final del estado de la finanzas de García

${ }^{65}$ ENRÍQUEZ DE GUZMÁN, 1960: 13. Llama la atención sobre esta cita, VAQUERO PIÑEIRO, 2007: 254.

${ }^{66}$ HERNANDO SÁNCHEZ, 2001: 336; HERNANDO SÁNCHEZ, 2007, vol. I: 198. Las relaciones de Gibraleón con ambos debieron de ser íntimas. Sobre el segundo, GIL, 2000, VOL. II: 50-62, 107-109; OLLERO PINA, 2009: 580-581. La carrera curial y episcopal del primero en FRENZ, 1986: 427 ( $\mathrm{n}^{\mathrm{o}}$ 1885) y RORC. Hombres todos de la misma generación, Gibraleón falleció en 1534, del Río en 1541 y Flores en 1540.

${ }^{67}$ Roma, 5 de octubre de 1526 para Toledo y Cuenca, ampliando la anterior de 1 de mayo para Sevilla, AGS, Patronato Real, 61, 8 .

${ }^{68}$ HERGENRÖTHER, 1884: $n^{\circ}$ 3132, 3924, 4283-4284, 4294-4295, 4366, 4372-4373.

${ }^{69}$ Bula de León, X, 1 de marzo de 1521, incorporada en la de Adriano VI, 31 de agosto de 1521, ASV, Instrumenta Miscellanea, doc. 7320, fasc. 1, ff. 1-22. 
de Gibraleón, la primera recopilaba las cuentas parciales que sus agentes le enviaban, incluyendo la que afectaba a beneficios de terceros, y, como recogía movimientos desde 1523 hasta 1534, proyecta una perspectiva diacrónica y más dinámica ${ }^{70}$.

García de Gibraleón recurrió a diferentes agentes para que gestionasen las rentas que poseía dispersas por la geografía castellana. Quien se encargó de cobrarlas en Sevilla fue Fernán Ruíz de Hojeda, que también actuó como su procurador ante el cabildo. Antes de ejercer como tal, este prebendado ya había demostrado con creces sus habilidades administrativas al servicio de su iglesia. En su juventud, siendo notario apostólico, había servido fielmente a Rodrigo de Santaella, canónigo magistral y arcediano de Reina en la catedral de Sevilla, y su intervención fue decisiva para que se levantara el Colegio de Santa María de Jesús que éste había fundado ${ }^{71}$. En 1525, después de doce años como mediorracionero, Ruíz de Hojeda obtendría una canonjía de la catedral de Sevilla gracias a las gestiones de Gibraleón, pero no fue un favor sin contrapartida. Tuvo que cederle las ganancias del primer año de la prebenda y en adelante estuvo obligado a liquidarle una pensión de 300 ducados, una cantidad que disminuía notablemente sus ingresos ${ }^{72}$. Como atestiguan sus cuentas, una carga tan pesada no afectó al rigor con qué realizó su tarea, por mucho que Pedro Suárez, después de la muerte de su tío, le enredase en un pleito que le costó meses de excomunión ${ }^{73}$. Lógicamente, Ruíz de Hojeda manejó el mayor volumen de rentas de su señor porque Sevilla era el objeto de los desvelos de éste y eje de su actividad mediadora. En 1526 administraba 38 piezas eclesiásticas que le pertenecían de la diócesis hispalense, pero en los años siguientes su número osciló entre 50 y 60; en general, 67 entre beneficios y prestameras diferentes. Las 31 cuentas o memorias contables que envió entre 1531-1534 que Gonzalo Suárez, fue recibiendo en Roma y reunió en su libro permiten comprobar la dedicación profesional que exigía su trabajo. Arrendaba los beneficios, cobraba el dinero de éstos y de las demás rentas, recaudaba su producto, con el que quizás especulaba y que luego vendía ${ }^{74}$, deducía los gastos y

${ }^{70} \mathrm{El}$ espolio en ASV, Instrumenta Miscellanea, doc. 7320. Juan Manuel Carretero ha estudiado el espolio a partir de otra fuente, CARRETERO ZAMORA, 78 (Buenos Aires, 2003): 7. La contabilidad en «Libro di Cuentos de Sevilla y otros lugares de Spaña dest[e] Año D. 1531», ASPF, Miscellanee Varie, vol. XXXI. Debo la localización de este documento al doctor Manuel F. Fernández Chaves.

${ }^{71}$ Sobre este personaje, HAZAÑAS, 1909: 492-499; GIL, 1987: XXVI-XXVII: OLLERO PINA, (Salamanca, 2005): 112-113, 176-178.

72 ASPF, Miscellanee Varie, vol. XXXI, f. 3.

${ }^{73}$ Desde 10 de septiembre de 1535 a 22 de septiembre de 1536, ACS, AACC, lib. 07062, f. 111, lib. 07063, f. 53v.

${ }^{74}$ Ventas de cereal de los beneficios de Utrera por Pedro y Francisco Suárez de 1516 a 1520 en AHPSPN, Protocolos de Utrera, leg. 23657PB, s. f. Ventas por Ruíz de Hojeda, en las 
remitía el neto por medio de mercaderes-banqueros genoveses en Sevilla que lo transferían a sus colegas romanos.

Los demás factores que empleó siguieron el mismo sistema según sus diócesis respectivas. En su mejor momento, García de Gibraleón llegó a coleccionar otros 46 beneficios y prestameras distribuidos entre Toledo (2), Salamanca (6), Burgos (9), Cuenca (9), Córdoba (10) y Cádiz (10). El canónigo de Cádiz Antonio de Cote, en concreto, gozó de autonomía en la administración de las rentas gaditanas. Éstas supusieron unos ingresos netos de casi 4.200 ducados entre 1523-1531, sin sumar las cantidades que recaudaba de los beneficios de terceros que también gestionaba, y cuando Gibraleón falleció, le faltaban por enviar 1.600 ducados, una vez deducidos los gastos ${ }^{75}$. En el obispado de Córdoba, con el mismo número de piezas eclesiásticas, la administración estuvo a cargo de Pedro de Angulo. Entre 1521-1532 este racionero cordobés que, además, le pagaba una pensión de 60 ducados, manejó un bruto de $2.020 .317 \mathrm{mrs}$. que dejaron libres casi $1.850 .000^{76}$. Se entiende entonces que le faltasen por transferir 3.513 ducados en 1534 de restos y rentas generadas hasta ese año.

El beneficio de Manzanares, en la diócesis de Toledo, fue administrado hasta 1530 por Alonso de Ayllón, maestrescuela y canónigo de Segovia, prebendas que heredó Pedro Ruíz de Ayllón, quien se haría cargo de la tarea después de este año. Mientras la recaudación y venta de los frutos quedaba a su criterio, la transferencia del dinero a Roma debía encaminarse por medio de banqueros italianos de Valladolid, según ordenaba Gibraleón, aunque a veces quedaba en manos de un cambista segoviano ${ }^{77}$. Entre 1529-1530 los beneficios que poseía en el obispado de Salamanca fueron administrados por Juan Scoto y don Pedro Imperial, un clérigo sevillano, amigo del maestro Silíceo, el futuro arzobispo de Toledo, que era tesorero y canónigo de su catedral ${ }^{78}$. Durante 1531 sus ganancias también las recibía Alfonso Neli, un mercader senés de Valladolid, por orden de Juan Suárez, para que cursara las consabidas transferencias ${ }^{79}$. Un año después todavía se despachaba dinero a Roma de esta procedencia, pero ya en 1533 este sobrino de Gibraleón, que era canónigo de León, dejó de hacerlo porque su tío le había cedido sus beneficios salmantinos con unas rentas que los subcolectores pontificios calculaban

cuentas del espolio en Sevilla, 6 de abril de 1536, ASV, Instrumenta Miscellanea, doc. 7320, fasc. 5, ff. 1-5.

${ }^{75}$ ASV, Instrumenta Miscellanea, doc. 7320, fasc. 2, ff. 1-6.

76 ASPF, Miscellanee Varie, vol. XXXI, ff. 81-86.

77 ASV, Instrumenta Miscellanea, doc. 7320, fasc. 3, ff. 1-6.

${ }^{78}$ Imperial moriría en 1533. Referencia a su testamento, Salamanca, 22 de abril de 1533, en la toma de posesión de unas casas que dejó a la catedral y al hospital del Cardenal de Sevilla, Sevilla, 3 de octubre de 1533, ACS, FHG, Caj. 10947, 7.

${ }^{79}$ Las cédulas sumaron 1.242.938 mrs., ASPF, Miscellanee Varie, vol. XXXI, ff. 64-67. 
en 430 ducados anuales ${ }^{80}$. No ocurrió así con los otros. Los de la diócesis conquense estuvieron bajo el cuidado de Juan del Pozo. Gibraleón tenía confianza plena en este canónigo de Cuenca, al que llamaba «reverendo señor hermano», y fue correspondido con una fidelidad inquebrantable. Muestra de su amistad es el trato que le daba en 1531 al instruirle sobre cuestiones de los beneficios de su diócesis. Le tranquilizaba respecto a las dificultades que ofrecía la posesión de los dos que había dejado vacante un familiar del cardenal del Monte porque éste «es mucho my señor». Esta mención a Antonio Ciocchi del Monte, que había sido uno de los cardenales más poderosos de los últimos pontificados, ayuda a entender la posición de García de Gibraleón en la trama de las influencias. Por otro lado, en la misma carta hizo referencia a un beneficio que, sin duda, había adquirido comprándolo ${ }^{81}$. El saldo de 1526-1529 lo envió Pozo a Roma, tal como estaba obligado, desde Cuenca ${ }^{82}$, pero el dinero de 1530-1531 lo remitió por medio de mercaderes genoveses de Valencia y así siguió haciéndolo posteriormente ${ }^{83}$. En Burgos se debía transferir también el dinero, pero las circunstancias eran diferentes. Como sabemos, las rentas que tenía en este obispado Juan de Lerma y pasaron a García de Gibraleón las gestionó Alonso de Lerma. Sin embargo, las bulas y los despachos que legalizaban su posesión, en competencia con el cabildo burgalés y discutida por un doctor Lerma, no llegaron hasta el año siguiente. Entre una y otra cosa no se comenzó a cobrar hasta 1525 y, aun así, más adelante hubo que resarcir a este último, quizás Gonzalo, el curial, con una enjundiosa compensación ${ }^{84}$. García de Gibraleón no hizo negocio con la herencia de Juan de Lerma, aunque cumplió la última voluntad de su amigo. El margen, después de hacer frente a los gastos y a la carga que arrastraba su administración hasta 1533 tuvo que dejarlo en depósito de Bernardino de Santa María, un banquero burgalés, para la dote de Leonor y ya no dispuso de tiempo para disfrutar de la renta liberada ${ }^{85}$.

Las pensiones que García de Gibraleón percibía sobre beneficios y prebendas le suponían entre 1.229 y 1.265 ducados anuales. Entre sus veintiocho o treinta pensionarios había once prebendados de Sevilla, incluido Fernán Ruíz de Hojeda, que pagaba la de mayor cuantía, con otros de Burgos, Cádiz, Córdoba, Cuenca y León, además de eclesiásticos que devengaban por bene-

${ }^{80}$ ASV, Instrumenta Miscellanea, doc. 7320, fasc. 2, ff. 1-22.

811 de febrero de 1531, ib.

${ }^{82}$ Gibraleón suscribió la quitanza en Roma, 21 de abril de 1531, ASPF, Miscellanee Varie, vol. XXXI, f. 76.

${ }^{83} \mathrm{Ib}$., f. $77 \mathrm{v}$.

${ }^{84}$ El pago de 1.151 ducados se le hizo en 1529, ASPF, Miscellanee Varie, vol. XXXI, f. 95, 96v. Conviene recordar que el doctor Pedro de Lerma, el erasmista cancelario de la Universidad de Alcalá, era también canónigo de Burgos, BATAILLON, 1966: 481-482.

${ }^{85}$ Ib., f. 98v; ASV, Instrumenta Miscellanea, doc. 7320, fasc. 1, ff. 1-22. 
ficios diversos. La suma, producto de su mediación, solo significaba una parte de las rentas que fue acumulando con tanta dedicación porque eran sus beneficios, tan concienzudamente acumulados, los que sumaban el primer capítulo de sus ingresos. Los datos que se desprenden de las cuentas de sus procuradores que llegaron a Roma son los que se plasman en el cuadro 1. La conclusión debe matizarse porque hay que considerar que se recogen periodos distintos. No obstante, no disminuyen su valor como proyección del volumen de rentas que llegó a captar, suponiendo siempre un mínimo respecto a la cantidad bruta real.

CUADRO 1. Ingresos brutos de los beneficios

\begin{tabular}{ccccc}
\hline Diócesis & Períodos & Ingresos $(\mathrm{mrs})$. & Media anual & $\%$ \\
\hline Sevilla & $1523-1532$ & 14.525 .311 & $1.452 .531,1$ & 62,37 \\
\hline Cuenca & $1526-1531$ & 1.144 .125 & $190.687,50$ & 8,19 \\
\hline Cádiz & $1523-1531$ & 1.667 .751 & $185.305,66$ & 7,96 \\
\hline Córdoba & $1521-1532$ & 2.020 .317 & $168.359,75$ & 7,23 \\
\hline Salamanca & $1525-1530$ & $952.291,5$ & $158.715,25$ & 6,81 \\
\hline Burgos & $1523-1533$ & 1.565 .019 & $142.274,45$ & 6,11 \\
\hline Toledo & $1529-1531$ & 92.938 & $30.979,33$ & 1,33 \\
\hline Jaén & 0 & 0 & 0 & 0,00 \\
\hline Total & & $21.967 .752,5$ & $2.328 .853,04$ & 100,00 \\
\hline
\end{tabular}

Los colectores del espolio, sin embargo, pretendieron, calculando los netos, evaluar las cantidades de dinero que todavía no había cobrado cuando murió ${ }^{86}$. Para ello estudiaron las cuentas, dedujeron los restos que se debían de los años anteriores a 1532 y determinaron el dinero que esperaban que se transfiriera a Roma del bienio 1533-1534 después de hacer frente a los gastos y las pérdidas (cuadro 2).

${ }^{86}$ ASV, Instrumenta Miscellanea, fasc. 2, ff. 1-6. 
CUADRO 2. Cálculos de ingresos netos de los beneficios en el espolio

\begin{tabular}{cccc}
\hline \multirow{2}{*}{ Diócesis } & \multirow{2}{*}{ Por cobrar mrs. } & \multicolumn{2}{c}{ Ingresos anuales } \\
\cline { 3 - 4 } & & Mrs. & $\%$ \\
\hline Sevilla & 4.137 .750 & 1.414 .875 & 58,56 \\
\hline Córdoba & 1.317 .375 & 243.700 & 10,08 \\
\hline Cádiz & 600.000 & 225.000 & 9,31 \\
\hline Salamanca & 322.500 & 161.250 & 6,67 \\
\hline Cuenca & 300.000 & 150.000 & 6,21 \\
\hline Burgos & 151.875 & 101.350 & 4,19 \\
\hline Jaén & 375.000 & 90.000 & 3,72 \\
\hline Toledo & 112.500 & 30.000 & 1,24 \\
\hline Total & 7.317 .000 & 2.416 .175 & 100,00 \\
\hline
\end{tabular}

Según su auditoría, la cámara creía, por consiguiente, que sería posible controlar los 19.512 ducados que no tardarían en llegar, como de hecho ocurrió con algunas pólizas, a los que habría que sumar otros 1.121 de las pensiones no cobradas de 1534, haciendo un total de 20.633. Asimismo, suponía que Gibraleón ingresaba al año 6.443 ducados netos de sus beneficios. La diferencia con la media de 6.210 que se extrae de las cuentas puede obedecer a una visión excesivamente optimista porque los cálculos se hicieron pensando que los últimos años significaban los ingresos más altos de la serie y tal vez se minusvaloró la detracción de los costes, pero respondería también al proceso de acumulación. La evolución del cargo de los beneficios de Sevilla entre 1523-1532 administrados por Ruíz de Hojeda, cuyos ingresos representaban el $60 \%$ del total de esta procedencia, contribuyen a sustentar esta interpretación. En el cuadro 3 la tendencia ascendente es indudable, tanto si se consideran los ingresos por sí mismos como si se comparan en relación a la proporción que suponían respecto a los ingresos en dinero que tuvo la mesa capitular de Sevilla durante los mismos años: 
CuAdro 3. Ingresos de los beneficios de Sevilla de García de Gibraleón / Mesa capitular de Sevilla ${ }^{87}$

\begin{tabular}{|c|c|c|c|c|}
\hline Años & Beneficios (mrs.) & $\%$ & Mesa capitular (mrs.) & $\%$ \\
\hline 1523 & 752.714 & 5,18 & 4.918 .258 & 15,30 \\
\hline 1524 & 675.637 & 4,65 & 7.467 .439 & 9,05 \\
\hline 1525 & 906.745 & 6,24 & 9.162 .778 & 9,89 \\
\hline 1526 & 722.706 & 4,97 & & \\
\hline 1527 & 1.387 .640 & 9,55 & & \\
\hline 1528 & 1.761 .371 & 12,13 & 10.229 .062 & 17,22 \\
\hline 1529 & 1.428 .750 & 9,83 & 8.657 .302 & 16,50 \\
\hline 1530 & 2.417 .591 & 16,64 & $10.974 .689,5$ & 22,03 \\
\hline 1531 & 2.439 .570 & 16,79 & 12.563 .286 & 19,42 \\
\hline \multirow[t]{2}{*}{1532} & 2.032 .587 & 13,99 & 12.146 .709 & 16,73 \\
\hline & 14.525 .311 & 100,00 & & \\
\hline
\end{tabular}

Por supuesto, las entradas reales del cabildo sevillano deben incrementarse con las que percibía de pan, trigo y cebada, para una evaluación correcta del volumen de su mesa. No obstante, es difícil que, a excepción del mismo arzobispo, existiese en su tiempo otro clérigo en la diócesis con mayor capacidad de extracción de renta. García de Gibraleón ingresaba incomparablemente más que el canónigo que más ganaba de la iglesia de su ciudad natal ${ }^{88}$. Ya solo con estos ingresos era un eclesiástico rico y sin obligaciones. Con todo, sin olvidar las pensiones, tampoco los beneficios agotaban las fuentes de su riqueza, mientras que a cambio no todo el dinero originado en Sevilla derivaba directamente a su bolsillo o se desviaba hacia Roma. Resulta imposible establecer cuánto en un caso o en otro dadas las características de las 31 cuentas de Ruíz de Hojeda que manejó Gonzalo Suárez porque no comprendían periodos homogéneos ni,

${ }^{87}$ Los datos de los beneficios, ASPF, Miscellanee Varie, vol. XXXI, ff. 7rv, 8, 20-22, 23-25, 26-28v, 30-33, 34-38, 45v-47v, 48-50. Para la mesa capitular, ACS, Mesa Capitular, libs. 00928, 07642, 07643, 07644, 07645, 07646, 07647 y 07648. No hay datos para 1526 y 1527.

${ }^{88}$ En 1531 y 1532 fue el inquisidor Antonio del Corro, que ganó 130.482,16 mrs., 356 fanegas, 11 almudes, 1 cuarto de trigo; 229 fanegas, 6 almudes de cebada y 125.779 mrs., 552 fanegas, 3 almudes de trigo, 259 fanegas, 3 almudes, 2 cuartos de cebada, respectivamente, más las gallinas. 
normalmente, el dinero se remitía enseguida después de la percepción de la renta. Además, al solaparse, su suma $(28.431 .748,5 \mathrm{mrs}$.) supera el dinero realmente manejado. Cabe agruparlas en tres categorías. Diez se referían específicamente a los beneficios de García de Gibraleón en Sevilla, cuyas entradas brutas son las que se recogen en el cuadro 3, doce a los beneficios de terceros residentes en Roma que Ruíz de Hojeda administraba y nueve consistían en las memorias de las cédulas y pólizas que éste fue enviando a Roma por medio de los mercaderes-banqueros. Éstas últimas se fechan entre el 10 de enero de 1531 y el 10 de junio de 1534 , pero se trata, como dice la primera, de la «memoria de los mrs. que yo el canónigo Fernand Ruys de Hojeda tengo reçibidos e cobrados por Garçía de Gibraleón», recogiendo ingresos desde varios años antes, hasta de 1523. Las partidas que las componen hacen posible definir no solo el origen del dinero sino que permiten indagar en la actividad de Gibraleón como agente.

CUADRO 4. Memorias de Ruíz de Hojeda (1531-1534)

\begin{tabular}{lcr}
\hline Concepto & Total (mrs.) & $\%$ \\
\hline Expediciones & 1.795 .243 & 15,19 \\
\hline Pensiones & $1.693 .958,5$ & 14,33 \\
\hline Beneficios de terceros & $948.46,5$ & 8,02 \\
\hline Beneficios de García de Gibraleón & 6.390 .169 & 54,01 \\
\hline Salarios & 281.870 & 2,38 \\
\hline Otros & 706.511 & 5,98 \\
\hline & 11.816 .398 & 100,00 \\
\hline
\end{tabular}

El dinero de las expediciones pagaba los trámites burocráticos que Gibraleón había realizado en Roma en servicio de sus clientes. Sus parientes, el cabildo catedralicio de Sevilla y una gran variedad de personajes, clérigos o no, acudieron a sus oficios para obtener en la curia dispensas de parentesco o de primera tonsura, absoluciones, bulas de beneficios y prebendas, breves, rescriptos, confirmaciones de donaciones, etc. Todos estos papeles los enviaba regularmente y Ruíz de Hojeda se encargaba de la distribución y su cobranza, pero no implicarían ganancias notables sino una proporción mínima del total. Igualmente, como se plasma en el cuadro 4, ocurriría con el salario con que le retribuía el cabildo por la procuración y la recepción de los ingresos de los beneficios de terceros que le enviaba asimismo Ruíz de Hojeda 
desde Sevilla. Aunque éste actuaba como el auténtico gestor, era en García de Gibraleón en quien confiaban los nueve individuos a los que pertenecían estas rentas eclesiásticas. De un modo u otro, todos le estaban vinculados por algún tipo de relación que le interesaba reforzar poniendo a disposición de los mismos sus contactos para asegurar su percepción sin que se tradujera en un negocio imprescindible para él, excepto que algunos de estos beneficios acabaron en sus manos. De todas formas, el dinero de esta procedencia que consignó Ruíz de Hojeda en las memorias no cubrieron el montante que manejó de estos beneficios y problemas semejantes ofrece el cálculo de los ingresos netos de las piezas eclesiásticas que García de Gibraleón poseía en Sevilla. El dinero de éstas que llegó a Roma según las cuentas particulares de Ruiz de Hojeda entre 1523-1532, ascendió a 6.752.740 mrs. Solo supone el $46,5 \%$ de los ingresos brutos, un porcentaje que debió de ser mayor porque a veces no es posible deslindar los costes y pérdidas, que incluían finiquitos de los capellanes, las fieldades de coger el pan, subsidios o quiebras, de los importes de las transferencias ${ }^{89}$, pero todavía la cantidad que se extrae de sus memorias es inferior (cuadro 4). Si nos ceñimos a sus cuentas específicas, la información para el periodo 1526-1532 de sus beneficios sevillanos es mucho más precisa. Se sumaron entonces unos ingresos brutos de 12.190.215 mrs. o, lo que es lo mismo, 32.507,24 ducados, de los que García de Gibraleón percibió en vida en Roma el 54 \%, 6.531 .154 mrs. El cuadro 5, en el que se concreta la distribución del dinero recaudado por Ruíz de Hojeda, ayuda a entender qué se hizo del resto.

CUADRO 5. Distribución de los ingresos de los beneficios de García de Gibraleón en Sevilla, 1526-1532 (mrs.)

\begin{tabular}{rrrrrrrrrr}
\hline Años & Cargo & En Roma & $\%$ & Costes & $\%$ & Alcances & $\%$ & Gastos & $\%$ \\
\hline 1526 & 722.706 & 359.650 & 49,76 & 124.481 & 17,22 & 0 & 0 & 238.575 & 33,01 \\
\hline 1527 & 1.387 .640 & 1.080 .442 & 77,86 & 184.723 & 13,31 & 0 & 0 & 122.475 & 8,82 \\
\hline 1528 & 1.761 .371 & 927.000 & 52,63 & 194.446 & 11,04 & 310.016 & 17,60 & 329.909 & 18,73 \\
\hline 1529 & 1.428 .750 & 246.000 & 17,22 & 229.812 & 16,08 & 161.786 & 11,32 & 791.152 & 55,37 \\
\hline 1530 & 2.417 .591 & 1.485 .312 & 61,44 & 351.783 & 14,55 & 149.700 & 6,19 & 430.796 & 17,81 \\
\hline 1531 & 2.439 .570 & 1.544 .250 & 63,29 & 234.070 & 9,96 & 159.600 & 6,54 & 501.650 & 20,56 \\
\hline 1532 & 2.032 .587 & 888.500 & 43,71 & 212.297 & 10,44 & 526.964 & 25,92 & 404.826 & 19,92 \\
\hline $1526-1532$ & 12.190 .215 & 6.531 .154 & 53,57 & 1.531 .612 & 12,56 & 1.308 .066 & 10,73 & 2.819 .383 & 23,13 \\
\hline
\end{tabular}

${ }^{89}$ Así en las cuentas de beneficios de 1523, 1524 y 1525, ASPF, Miscellanee Varie, vol. XXXI, ff. 7-8. 
En principio, hay que señalar que, al finiquitar estas cuentas, Ruíz de Hojeda había dejado sin emplear casi el $11 \%$ del cargo. Este dinero, que sumó 1.308.066 mrs., es el que los funcionarios de la cámara esperaban recibir en Roma después de la muerte de Gibraleón, con lo cual realmente se situaría casi en los dos tercios del bruto el que tenía este destino, una proporción que parece más cercana a la realidad ${ }^{90}$. Si a ello se añade que un $12,5 \%$ se consumía en el mantenimiento de los beneficios, poco menos de la cuarta parte fue a cubrir las inversiones o gastos, que ambas definiciones admite, que su propietario ordenó realizar en Sevilla. No se pretende elevar la moral económica de Gibraleón a paradigma de la que siguieron los clérigos absentistas acaparadores de rentas, ni siquiera de la de sus colegas curiales, pero estos costes y gastos formarían la porción de renta extraída que no fue desviada al exterior. Algunos parecen inevitables, otros, sin embargo, excepcionales. En cualquier caso, fueron los sobrinos y sobrinas de Gibraleón los beneficiarios del $17 \%$ de los gastos, empleándose casi la mitad en su fundación. No tanto por lo poco que gastó en la dotación de doncellas, sino porque entre 15261532 invirtió 859.030,5 mrs. en la compra de tributos y casas en Sevilla para la capilla hasta $1530 \mathrm{y}$, desde este año, otros 455.493 sirvieron para sufragar la compra de bienes y obras decorativas para él o para la misma. Con dineros de los beneficios de 1530 Ruíz de Hojeda «pagó a Morales, pintor, por quatro paños que pintó de los triunfos de Petrarca» $16.875 \mathrm{mrs}$. y otros $18.375 \mathrm{mrs}$. «por la segunda cama que enbió de pintar e lienços» ${ }^{91}$. Cristóbal de Morales, como dedujo Ch. R. Post y aceptó J. M. Serrera, pintó el retablo del altar de la capilla de las Doncellas y, aunque las cuentas no aportan otra noticia de su intervención, $319.289 \mathrm{mrs}$. de los ingresos de 1532 fueron utilizados para adelantar o terminar la obra. Con ellos se pagaron a los artistas que estuvieron trabajando en ella ${ }^{92}$.

García de Gibraleón creyó que las rentas eclesiásticas que con tanta paciencia había ido reuniendo a lo largo de su vida formaban un patrimonio que podía ser transmitido a su arbitrio. Con este convencimiento fue disponiendo las resignaciones de sus beneficios entre sus parientes y criados. Su testamento ratificaría el premio de sus servidores y el bienestar de la familia, mientras que procuraría la continuidad de la capilla y la hermandad de la catedral de Sevilla con la dotación de su legado. Para asegurar que así fuera nombró al-

${ }^{90}$ El cálculo de estos «restos» por recibir de la cámara, 1.308.200 mrs., prácticamente coincide. Las diferencias por anualidades son muy pequeñas, ASV, Instrumenta Miscellanea, doc. 7320, fasc. 2, ff. 1-6.

91 ASPF, Miscellanee Varie, vol. XXXI, f. 37rv.

92 ASPF, Miscellanee Varie, vol. XXXI, f. 49rv. Debe recordarse que Morales incluyó un retrato de García de Gibraleón, cuyo modelo debió enviar este mismo de Italia, en el panel que representa la ceremonia de entrega de las dotes a las doncellas. Sobre la atribución a Cristóbal de Morales de la pintura del retablo, SERRERA, 1984: 380-384. 
baceas a dos poderosos eclesiásticos curiales que habían sido sus amigos, el cardenal Esteban Gabriel Merino y Pedro de Flores, el citado obispo de Castellamare, entonces regente de la cancillería apostólica ${ }^{93}$. Pero Gibraleón no sospechó que su misma riqueza haría imposible el cumplimiento de su voluntad. Para desgracia de sus herederos, la cámara apostólica consideró su herencia como un espolio y, tras su muerte, el 26 de diciembre de 1534, se lanzó sobre ella. El 10 de febrero siguiente, cuando, unos días después de su regreso de Roma, tuvo noticia del fallecimiento de su tío, Pedro Suárez, el mozo, pidió licencia al cabildo de Sevilla porque quería volver a la corte pontificia para litigar en defensa de las resignaciones ${ }^{94}$. Su información era cierta. A finales del mes anterior Paulo III había diputado a una comisión la investigación de la legalidad de la herencia de García de Gibraleón, en la que a los dos ejecutores testamentarios se añadieron Girolamo Ghinucci, auditor general de la cámara y obispo de Worcester, el auditor y obispo de Pesaro Giacomo Simonetta, que al poco recibirían el capelo cardenalicio, y Luis Gómez, el erudito y prestigioso auditor de la Rota y obispo de $\mathrm{Sarno}^{95}$. Esta composición sugiere la importancia que poseía un asunto que se trató con tanta celeridad. En marzo, Giovanni Poggio, el nuncio y colector general en España, iniciaba el proceso de posesión en nombre de la cámara de los beneficios que García de Gibraleón había disfrutado en las diócesis españolas y de confiscación de los capitales que de él habían quedado ${ }^{96}$. Un año después, ante el mismo Poggio, el subcolector don Gonzalo Cabezas, arcediano de Écija, lo concluía liquidando los gastos hechos en Sevilla y cerrando las cuentas de la administración de Ruíz de Hojeda ${ }^{97}$. Este acto simbolizaba un final de la carrera de García de Gibraleón posterior a su muerte. Su balance es ambiguo. Posiblemente, la mayoría de sus beneficios fue redistribuida entre clérigos que le eran desconocidos y el cabildo sevillano, al que tanto había servido, como hemos visto, desenterró los procesos inquisitoriales de la familia para frenar el intento de otro García de Gibraleón de convertirse en canónigo. Pero tanto éste como sus otros sobrinos mantuvieron en sus manos al menos los benefi-

${ }^{93}$ Desde 1530 Gibraleón recibía de Merino un salario anual de cien ducados, ASPF, Miscellanee Varie, vol. XXXI, ff. 11, 16v. El 5 de junio de 1534 García de Gibraleón escribía al maestrescuela de Segovia, Pedro Ruíz de Ayllón, interesándose sobre los importes de los beneficios de Merino y Flores que administraba por él, ASV, Instrumenta Miscellanea, doc. 7320, fasc. 3, ff. 1-6. Sobre la importantísima figura de Esteban Gabriel Merino las reseñas biográficas de GOÑI GAZTAMBIDE, 1987: 483-489; FERNÁNDEZ CONTI, 2000: 283-284.

9410 de febrero de 1535, ACS, AACC, lib. 07062, f. 48v.

95 Breve de Paulo III a Giovanni Poggio, nuncio y colector en España, Roma, 25 de enero de 1535, ASV, Instrumenta Miscellanea, doc. 7320, fasc. 1, ff. 1.22.

${ }^{96}$ La relación de beneficios a expropiar en el breve a él dirigido de Roma, 12 de enero de 1535. Se inició en Cuenca con la comisión a Francisco de Mendoza, prior de Aroche, el 12 de abril.

${ }^{97}$ Sevilla, 6 de abril de 1536, ASV, Instrumenta Miscellanea, doc. 7320, fasc. 5, ff. 1-5. 
cios que había logrado para ellos y la fundación con que había pretendido perpetuarse en la catedral de su patria perviviría durante siglos sin que nadie volviera a recordar el trágico pasado de sus padres y sus hermanos.

\section{BIBLIOGRAFÍA}

Alonso García, David, Fisco, poder y Monarquía en los albores de la modernidad: Castilla, 1504-1525, Madrid, Tesis doctoral, Universidad Complutense, 2004.

Andrés Díaz, Rosana de, El último decenio del reinado de Isabel I a través de la tesorería de Alonso de Morales (1495-1504), Valladolid, Universidad de Valladolid, 2004.

Bataillon, Marcel, Erasmo y España. Estudios sobre la historia espiritual del siglo XVI, México, FCE, 1966.

Bataillon, Marcel, «La chasse aux bénéfices vue de Rome par Juan Páez de Castro», en Mélanges en l'honneur de Fernand Braudel. 1. Histoire économique du monde méditerranéen, 1450-1650, Toulouse, Privat, 1973, I; 81-94.

Carretero Zamora, Juan Manuel; Alonso García, David, Hacienda y negocio financiero en tiempos de Isabel la Católica: el libro de hacienda de 1503, Madrid, Editorial Complutense, 2003.

Carretero Zamora, Juan Manuel, «La colectoría de España en época de Carlos V: cuentas del nuncio y colector General Giovanni Poggio (1529-1546)», Cuadernos de historia de España, 78 (2003): 102-135, [en línea]. Disponible en: http: //www.scielo.org.ar/scielo.php?script=sci_arttext\&pid=S0325-11952003000100005 \&lng=es\&nrm=iso

D'Amelia, Marina, «Economia familiare e sussidi dotali. La politica della Confraternita dell'Annunziata a Roma (secoli XVII-XVIII)», Cavaciocchi, Simonetta (a cura di), La donna nell'economia, secc. XIII-XVIII. Atti della "Ventunesima settimana di studi», 10-15 aprile, 1989, Florencia, Le Monnier, 1990; 195-215.

Dandelet, Thomas, «Spanish Conquest and Colonization at the Center of the Old World: The Spanish Nation in Rome, 1555-1625», The Journal of Modern History, 69: 3 (1997), 479-511.

Dandelet, Thomas, La Roma española (1500-1700), Barcelona, Crítica, 2002.

Delumeau, Jean, Vie économique et sociale de Rome dans la seconde moitié du XVIe siècle, París, E. de Brocard, 1957-1959, 2 vols.

Enríquez de Guzmán, Alonso, Libro de la vida y costumbres de Don Alonso Enríquez de Guzmán, Keniston, Hayward (publicado por), Madrid, Atlas, 1960.

Eubel, Conradus, Hierarchia Catholica Medii Aevi sive Summorum Pontificum, S.R.E. Cardinalium Ecclesiarum Antistitum Series. Volumen Tertio. Saeculum XVI ab anno 1503, Padua, Libr. Regensbergianae, 1960 [1913].

Fernández Alonso, Justo, «Instrumentos originales en el Archivo de Santiago de los Españoles», Anthologica Annua, 4 (1956), 499-547. 
Fernández Alonso, Justo, «Nuncios, colectores y legados pontificios en España de 1474 a 1492», Hispania Sacra, 10 (1957), 33-90.

Fernández Alonso, Justo, «Santiago de los Españoles, de Roma, en el siglo XVI», Anthologica Annua, 6 (1958), 9-122.

Fernández Conti, Santiago, «Merino, Esteban Gabriel», en Martínez Millán, José (dir.), Carlos Morales, Carlos Javier de (coor.), La corte de Carlos V. Segunda parte, Los consejos y los consejeros de Carlos V, Madrid, Sociedad Estatal para la Conmemoración de los Centenarios de Felipe II y Carlos V, D.L., 2000, 283-284.

Fernández de Córdova Miralles, Álvaro, Alejandro VI y los Reyes Católicos. Relaciones politico-eclesiásticas (1492-1503), Thesis ad Doctoratum in Theologia totaliter edita, Pontificia Universitas Sanctae Crucis, Facultad Theologiae, Romae, 2005.

Forcella, Vincenzo, Inscrizioni delle chiese e d'altri edificii di Roma dal sec. XI fino ai giorni nostri, Roma, III, Tipografia dei Fratelli Bencini, 1876.

Frenz, Thomas, Die Kanzlei der Päpste der Hochrenaissance (1471-1527), Tübingen, Max Niemayer Verlag, 1986.

Frenz, Thomas, Repertorium Officiorum Romanae Curiae auctore Th. Frenz, wwws.phil.uni-passau.de/histhw/RORC/

Fuente, Vicente de la (editor), Cartas de los secretarios del Cardenal D. Fr. Francisco Jiménez de Cisneros durante su regencia en los años 1516 y 1517, Madrid, Imprenta de la Sra. Viuda e Hijo de D. Eusebio Aguado, 1875.

Gil, Juan, El libro de Marco Polo anotado por Crtistóbal Colón. El libro de Marco Polo de Rodrigo de Santaella, Madrid, Alianza Editorial, 1987.

Gil, Juan, Los conversos y la Inquisición sevillana, Sevilla, Universidad de SevillaFundación El Monte, 2000-2003, 8 vols.

Goñi Gaztambide, José, «Merino, Esteban Gabriel», en Aldea, Quintín; Vives, José; Marín Tomás, Diccionario de Historia Eclesiástica de España. Suplemento, Madrid, Instituto Enrique Flórez, 1987; 483-489.

Grassi, Paride de, El diario di Leone X di Paride de Grassi, maestro delle cerimonie pontificie, dai volumi manoscritti degli Archivi Vaticani della S. Sede con note di M. Armellini, Roma, Tipografia della Pace di F. Cuggiani, 1884.

Hazañas, Joaquín, Maese Rodrigo, 1444-1509, Sevilla, 1909.

Hergenröther, Joseph, Leonis X Pontificis maximi Regesta gloriosis auspicis Leonis D. P.P. XIII. feliciter regnantis e tabularii Vaticani manuscriptis voluminibus aliisque monumentis adjuvantibus tum eidem Archivio addictis tum aliis eruditis viris, Friburgo, Herder, 1884.

Hernando Sánchez, Carlos José, El reino de Nápoles en el Imperio de Carlos V. La consolidación de la conquista, Madrid, Sociedad Estatal para la Conmemoración de los Centenarios de Felipe II y Carlos V, D.L., 2001.

Hernando Sánchez, Carlos José, «Un tratado español sobre la corte de Roma en 1504: Baltasar del Río y la sátira anticortesana», en Hernando Sánchez, Carlos José (coordinador), Roma y España: un crisol de la cultura europea en la Edad Moderna (Actas del Congreso Internacional celebrado en la Real Academia de España en Roma del 8 al 12 de mayo de 2007), Madrid, Sociedad Estatal para la Acción Cultural Exterior, 2007, I; 189-237. 
Hofmann, W. V., Forschungen zur Geschichte der Kurialen Behörden vom Schisma bis zur Reformation. Band. II. Quellen, listen und Exkurse, Roma, Verlag von Loescher \& C 1914.

Kettering, Sharon, Patrons, Brokers, and Clients in Seventeenth-Century France, New York/Oxford, Oxford University Press, 1986.

Llorens Cisteró, José María, «Juan Escribano, cantor pontificio y compositor (m. 1557)», Anuario Musical, 12 (1957), 97-122.

Llorens Cisteró, José María, «Cantores de los papas que 'pontificaron’ en el siglo XV», Anuario de Estudios Medievales, 18 (1988), 605-626.

Matute y Gaviria, Justino, Hijos de Sevilla señalados en santidad, letras, armas, artes o dignidad por D. Justino Matute y Gaviria, anotados y corregidos por la redacción del Archivo Hispalense, Sevilla, en las oficinas de El Orden, 18861887,2 vols.

Ollero Pina, José Antonio, «Una familia de conversos sevillanos en los orígenes de la Inquisición: Los Benadeva», Hispania Sacra, 40 (1988), 45-105.

Ollero Pina, José Antonio, «Clérigos, universitarios y herejes. La Universidad de Sevilla y la formación académica del cabildo eclesiástico», Universidades Hispánicas. Modelos territoriales en la Edad Moderna (I), Miscelánea Alfonso IX (2005), 107-195.

Ollero Pina, José Antonio, «La Historia Parthenopea de Alfonso Fernández Benadeva, la Inquisición y otras cosas de familias», en Álvarez Santaló, León Carlos (coordinador), Estudios de Historia Moderna en Homenaje al profesor Antonio García-Baquero, Sevilla, Universidad de Sevilla, 2009; 549-583.

Ortega Martín, Joaquín, Un reformador pretridentino: Don Pascual de Ampudia, obispo de Burgos (1496-1512), Roma, Instituto Español de Historia Eclesiástica, 1973.

Partner, Peter, Renaissance Rome, 1500-1559. A Portrait of a Society, Berkeley-Los Angeles-Londres, University of California Press, 1979.

Partner, Peter, The Pope's Men. The Papal Civil Service in the Renaissance, Oxford, Clarendon Press, 1990.

Sánchez Herrero, José; Álvarez Márquez, Mª Carmen, «Fiestas y devociones en la Catedral de Sevilla a través de las concesiones medievales de indulgencias», $R e$ vista Española de Derecho Canónico, 46, 126 (1989), 129-178.

Serrera Contreras, Juan Miguel, «Pinturas y pintores del siglo XVI en la catedral de Sevilla», en Chueca Goitia, Fernando (prólogo), La Catedral de Sevilla, Sevilla, Ediciones Guadalquivir, 1984; 344-382.

Sevilla, Iglesia de, Estatutos y constituciones de la Santa Iglesia de Sevilla, [Sevilla], s. a.

Terrateig, Barón de, Política en Italia del rey Católico, 1507-1516. Correspondencia inédita con el embajador Vich, Madrid, CSIC, 1963, 2 vols.

Vaquero Piñeiro, Manuel, «La presencia de los españoles en la economía romana (1500-1527)», En la España Medieval, 13 (1993), 287-305.

Vaquero Piñeiro, Manuel, «Los españoles en Roma y el Saco de 1527», en Hernando Sánchez, Carlos José (coordinador), Roma y España: un crisol de la cultura eu- 
ropea en la Edad Moderna (Actas del Congreso Internacional celebrado en la Real Academia de España en Roma del 8 al 12 de mayo de 2007), Madrid, Sociedad Estatal para la Acción Cultural Exterior, 2007, I; 249-266.

Vázquez Santos, Rosa, «La iglesia de San Giacomo degli Spagnoli a la luz del manuscrito 15449 del Archivio Storico Capitolino y otras fuentes del siglo XVII», en Hernando Sánchez, Carlos José (coordinador), Roma y España: un crisol de la cultura europea en la Edad Moderna (Actas del Congreso Internacional celebrado en la Real Academia de España en Roma del 8 al 12 de mayo de 2007), Madrid, Sociedad Estatal para la Acción Cultural Exterior, 2007, II; 667-677.

Wright, Irene, «The Early History of Jamaica, 1511-1536», English Historical Review, 36 (1921), 70-95.

Recibido: 27/05/2014

Aprobado: 29/12/2015 